\title{
ハイブリッド励磁形ブラシレス同期機の 動作原理と基本特性
}

$\begin{array}{llllllll}\text { 正 員 } & \text { 水 } & \text { 野 } & \text { 孝 } & \text { 行 } & \text { (明 } & \text { 電 } & \text { 舎) } \\ \text { 正 員 } & \text { 永 } & \text { 山 } & \text { 和 } & \text { 俊 } & \text { (明 } & \text { 電 } & \text { 舎) } \\ \text { 正員 } & \text { 足 } & \text { 利 } & & \text { 正 } & \text { (明 } & \text { 電 } & \text { 舎) } \\ \text { 正員 小 } & \text { 小 林 } & \text { 忠 } & \text { 夫 } & \text { (明 } & \text { 電 } & \text { 舎) }\end{array}$

\author{
Basic Principles and Characteristics of Hybrid Excitation Type Synchronous Machine \\ Takayuki Mizuno, Member, Kazutoshi Nagayama, Member, Tadashi Ashikaga, Member, Tadao Kobaya- \\ shi, Member (MEIDENSHA CORPORATION)
}

Permanent magnet type synchronous machines have been widely used for industrial applications. It is commonly known that they are operated at high efficiency since no excitation input is required. However it is difficult to control the air gap magnetic flux, because the magnetic flux is determined by the property of the permanent magnet and approximately kept constant.

On the other hand synchronous machines with the field winding make it easy to control the air gap magnetic flux. But the copper loss of the field winding becomes large at the rated load.

In order to realize the magnetic flux control easily and improve the performance of the conventional synchronous machine, we propose a hybrid excitation type synchronous machine (HSY) with the permanent magnets and the field winding. Advantages of HSY are (1) it has no brushes (maintenance free), (2) required excitation input is small (high efficiency), (3) it is easy to get a sufficient magnetic flux control, and others. Therefore, HSY has a great possibility to use for various applications.

In this paper, basic principles and characteristics of HSY are mainly discussed and made clear.

キーワード：同期機，永久磁石，界磁巻線，ハイブリッド励磁，界磁制御，有限要素法

\author{
1.まえがき \\ 永久磁石式同期機（以下, PMSY と略記）は，ブラシ \\ レス構造であることはもとより，励磁入力が不要となり， \\ 他の回転機に比較して効率が高いという特徵を有してい \\ る。このため, 一般産業においても幅広く使用されるよう \\ になってきた。また, 希土類磁石の出現により数十 $\mathrm{kW}$ \\ 級のPMSYも容易に製作できるようになっている。しか \\ し, 界磁磁束が永久磁石の特性によってほほ一定に保たれ \\ るため, 巻線誘起電圧が回転数とともに変化し, 電動機と \\ しての定出力運転，あるいは発電機としての定電圧運転を \\ 行うような場合には不利な点が多いことも事実である。電 \\ 動機としては，磁石埋込形PMモー夕を用いた弱め界磁

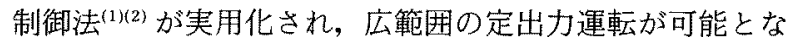 \\ っている。しかし，界磁に希土類磁石のような高性能磁石 \\ を用いた場合には，弱め界磁制御のために大きな電機子電 \\ 流が必要となること,この電流は無負荷でも必要となるこ
}

となどから，特に軽負荷時の効率を悪化させる原因となっ ている(3)。また, PMSYを用いた直流発電システム(4)で は, 定格容量相当のチョッパやコンバータが必要になり, システムとして大形となる問題もある。

一方, 巻線界磁形同期機（以下, FWSY と略記）では, 界磁巻線に流す直流界磁電流により界磁磁束が容易に調整 できるので，前述のような PMSYについての界磁制御上 の問題点は少ないように思われる。特に,FWSYを用い た発電システムでは, 小形小容量の励磁装置によって電圧 制御が容易に行えることも周知のことである。しかし，界 磁巻線，ブラシ括よびスリップリングなどが必要となるた め, 回転機としての体格の増大, 定格運転時の界磁損によ る効率低下，保守の必要性など, PMSY とは異なった問 題点が存在することになる。

したがって，これらの同期機の応用範囲はその励磁方式 に大きく左右されるとみることもでき，永久磁石界磁と巻 線界磁との利点を兼ね備えたような同期機が製作できれ 
ば，同期機の汎用性をより向上させることができるものと 考える。このような観点から，ここでは永久磁石界磁と直 流界磁巻線とを備えたハイブリッド励磁形同期機(5)(6) (以 下，HSY と略記する）を提案し，主としてその動作原理 および基本特性を理論的および実験的に明確にするととも に，応用の可能性について検討する。

まず, 永久磁石界磁と直流界磁巻線とを備え, 直流界磁 電流によりギャップ磁束が調整できるHSY の基本構造を 示し，その動作原理および他の同期機に比較した場合の得 失を明確にする。HSYの特徴は，ブラシレス化を前提 に, 永久磁石界磁の磁路と界磁巻線の磁路とを基本的に独 立させ, 小さな界磁巻線起磁力によって, ギャップ主磁束 の等価的な増減を可能としたことにある。このため, HSY は無保守化が可能であるとともに, 効率よく界磁制 御が行えることになる。

次に, 有限要素解析のための実用的な二次元モデルを考 え, 試作機の無負荷および負荷特性の解析を行う。負荷特 性の解析は, 有限要素法の解析と実システムでの制御方式 の関係が明確となるように, 二軸理論により導出した磁束 密度基準の電圧方程式扝よびトルクの式に基づいている。

さらに，無負荷および負荷特性の実測值と解析結果との 比較検討を行い，HSY の基本特性を明らかにするととも に，同期機としての電動機(7) るいは発電機(8) として, 十分応用できる可能性があることを示す。

\section{HSY の構造と動作原理}

〈2・1〉基本構造 提案する HSY の基本構造を図 1

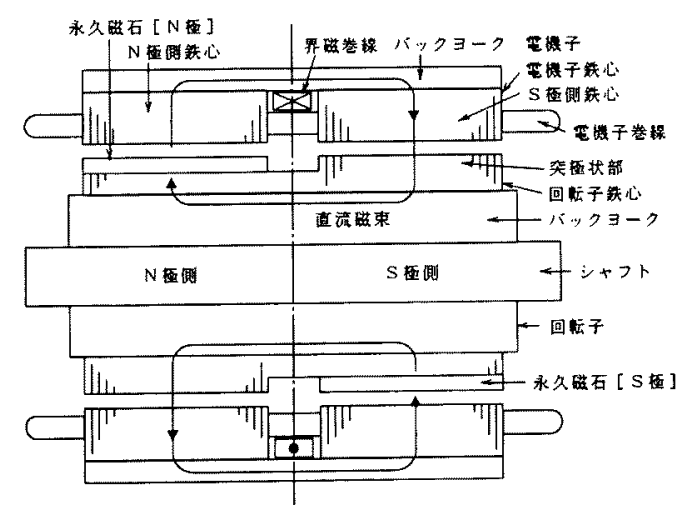

(a) HSY O横断面

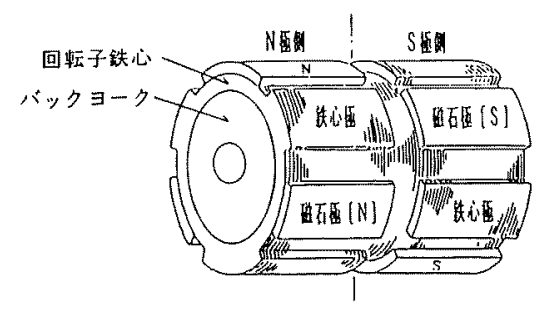

(b) 回転子の構造

図 1 HSY の基本構造

Fig. 1. Basic construction of HSY.
に示す。同図 ( a ) はHSY の横断面, (b)は回転子の構造 図を示している。

HSY の電機子側は基本的にホモポーラ形同期機(9) と同 一であり, 電機子鉄心を二つの部分に分け, 円周方向に巻 いた界磁巻線を鉄心中央部のスペース部に装着している。 この巻線に直流の界磁電流を流すことによって, ギャップ 磁束の等価的な増減が可能となる。二つの電機子鉄心は, 外側のバックヨークにより機械的および磁気的に結合され ている。また, 電機子鉄心には円周方向にスロットが設け てあり，通常の三相交流巻線が施されている。

同様に，回転子側も電機子に対応して二つに分かれてい るが, 説明の都合上, 図面の左側（N極磁石が装着）を $\mathrm{N}$ 極側, 右側 ( $\mathrm{S}$ 極磁石が装着) を $\mathrm{S}$ 極側と称すること にする。N 極側では, エアギャップ面が $\mathrm{N}$ 極となる永久 磁石を1極抢きに張り付け，他の極部分は積層鉄心により 突極を形成している。以下，磁石のある極を磁石極，鉄心 による突極を鉄心極と称する。一方, $\mathrm{S}$ 極側では, $\mathrm{N}$ 極 側の鉄心極と同一軸上にある極にはエアギャップ面が S 極となる永久磁石を張り付け， $\mathrm{N}$ 極側の磁石極と同一軸 上にある極には鉄心極を形成した構造となっている。ま た，両極側の回転子鉄心は内側のバックコークによって機 械的および磁気的に結合されている。

〈2・2〉動作原理 ここで, 電機子中央部の界磁巻線 に図1（a）に示すような方向で界磁電流を流すと, 永久磁 石部分は磁気抵抗が大きいので, ほとんどの磁束は回転子 の鉄心極を通ることになる。すなわち，「電機子バックヨ ーク $\rightarrow \mathrm{S}$ 極側電機子鉄心 $\rightarrow \mathrm{S}$ 極側鉄心極 $\rightarrow$ 回転子バック $\exists ー ク \rightarrow \mathrm{N}$ 極側鉄心極 $\rightarrow \mathrm{N}$ 極側電機子鉄心 $\rightarrow$ 電機子バッ クヨーク」といった経路で直流磁束が発生する。この磁束 の方向拈よび大きさは界磁電流の向き抢よび大きさによっ て調整できることになる。

一方，永久磁石として希土類磁石のような保持力の大き なものを使用すると，多少の外部磁界が加わっても減磁の 心配はなく, 磁石の極性で決まる方向にほほ一定の磁束を 発生すると考えることができる。したがって, 界磁電流に よる磁束を無視すれば, 多少の漏机磁束は存在するもの の, 基本的に $\mathrm{N}$ 極側磁石から出た磁束は, 電機子バック ヨークを通り S 極側磁石に入ることになる。

このように，界磁巻線抢よび永久磁石に上る磁束の経路 はそれぞれ独立して考えることができる。しかし，実際に はこれらの磁束が合成された形で存在寸ることになり，以 下に示すように, 界磁電流の調整によって等価的なギャッ プ磁束の増減が可能となる。

（1）無励磁の場合（界磁電流： $I_{f}=0 \mathrm{~A}$ ）この場合 のギャップ磁束は, 永久磁石および磁気回路の特性によっ て决まり，ギャップ磁束は磁石極のみに存在することにな る。しかし，回転子が回転していると電機子巻線は $\mathrm{N}$ 極 側あるいは S 極側のどちらかの磁束を切ることになり， 電機子巻線には電圧が誘起される。このときの磁束の方向 を図示すると図 2 (a)のようになる。ただし，図2では電 


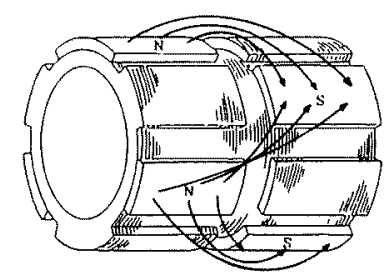

(a) 無励磁の場合 $\left(I_{f}=0\right)$

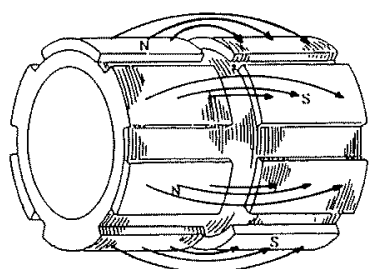

(b) 減磁した場合 $\left(I_{f}<0\right)$

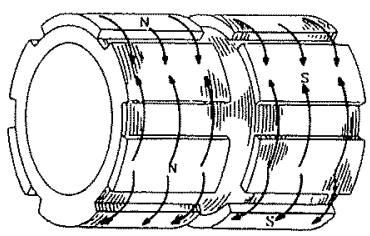

(c) 堌磁した場合 $\left(I_{f}>0\right)$

図 2 HSYの動作原理

Fig. 2. Principle of HSY.

機子鉄心およびバックヨーク部分を省略し，磁束の経路を 概念的に示している。

（2）減磁する場合（界磁電流： $I_{f}<0$ とする）界 磁電流の方向は図 1 ( a ) と同一である。磁石による磁束は (1) と同様で，これに界磁巻線による磁束が重胃される。 前述のように界磁巻磁による磁束のほとんどが鉄心極を通 ることになるが，この場合，S 極側の鉄心極は磁束が回転 子側に入る方向（S 極）であり， $\mathrm{N}$ 極側の鉄心極は磁束 が回転子側から出る方向 ( $\mathrm{N}$ 極) となる。したがって, 回転子の同一軸上で見た場合, 両極側での磁束の方向が逆 向きとなるため, 電機子巻線に誘起される電圧には相殺さ れる成分が発生し，界磁電流を０とした場合より誘起電圧 が小さくなる。すなわち，等価的にギャップ磁束を弱めた ことになる。また，磁石と界磁巻線による合成磁束の分布 状況は複雑となるが，特に鉄心極と磁石極の磁束の量が同 一の場合には，図2(b)のようになる。

（3）堌磁する場合（界磁電流： $I_{f}>0$ とする）界 磁電流の方向は図 1 (a)の逆である。この場合も (2) と同 様に考えることができるが, 界磁巻線による磁束の方向が 逆となり，S極側の鉄心極は磁束が回転子側から出る方向 ( $\mathrm{N}$ 極)， $\mathrm{N}$ 極側の鉄心極は磁束が回転子側に入る方向（S 極）となる。したがって，回転子の同一軸上で見た場合， 両極側での磁束の方向が同一となるため，電機子巻線に誘 起される電圧は界磁電流を 0 とした場合より大きくなる。 すなわち，等価的にギャップ磁束を強めたことになる。鉄 心極と磁石極の磁束の量が同一の場合, 磁束分布は図 2 (c)のようになる。

以上の原理に基づき, 直流界磁電流を変化させることに よって, HSYのギャッブ磁束および電機子巻線誘起電圧 を等価的わよび連続的に調整することが可能となる。

〈2・3〉 HSY の得失 HSYの構造抢よび動作原理は 以上のとおりであるが，その構造上，種々の得失が存在す ることも事実である。ここでは HSY として予想される得 失についてまとめておく。

（1）HSYの体格 HSYでは直流界磁のための界 磁巻線とバックヨークが必要となる。このため, 同一容量 として設計した場合, 一般にHSYの体格はPMSYより 大きくなるとみることができる。しかし，設計によって は, 直流界磁によりギャップ磁束密度をPMSYより大き くすることができ，またバックヨークとしてフレームを代 用することもできるので, PMSY の体格と同等とするこ とも可能であると考える。一方, FWSY と比較すると, 回転子上の巻線, ブラシおよびスリップリングなどが不要 となることから，一般に HSY のほうが小形化できるとい える。

（2）制御装置の構成 HSYでは直流界磁が必要と なるので，電動機として使用する場合にはPMSY として の駆動装置に加えて，界磁調整用の励磁装置およびその制 御が必要となる。しかし, 後述するように, HSYの励磁 容量は比較的小さく励磁装置も小形化できるので, 電動機 の駆動装置内に収納することが可能となり，駆動装置の体 格はPMSY と同程度にできるものと考える。また，制御 的には界磁巻線による界磁制御に加え，従来の電機子電流 による弱め界磁制御(1)22)なども行うことができ，より高機 能な制御を実行できる可能性もある。一方, 発電機として 用いた場合には，PMSYでは定格容量相当のチョッパや コンバータが必要となるが(4), HSYでは小容量の小形で 簡単な励磁装置(8)で構成することができ，この場合の制 御装置はHSY のほうが数段小形化できるとみることがで きる。また，FWSYと比較しても，必要な界磁起磁力の 多くを永久磁石が分担することになるので，励磁容量が小 さく，制御装置も小形化できる。

（3）励磁容量と効率 HSY を定格負荷で運転した 場合, 界磁損が多い分, PMSYより効率が悪くなること は事実である。しかし，界磁に必要な容量は，後述の試作 機の場合, 最大でも $160 \mathrm{~W}$ 程度と少なく, 全体の効率に 与える影響は非常に少ないと考える。特に, PMSYにつ いて弱め界磁制御を行うような場合の軽負荷領域では, HSYでは界磁損が無視できるようになるのに対し， PMSYでは弱め界磁制御のための電機子電流による銅損 が支配的となり効率も低下する(3)。したがって，HSYの 使用によりこの領域での効率の改善ができるものと考光 る。また，FWSYに対しては，励磁容量が小さくなると ともに，ブラシ損もなくなるので, 効率も全体的に向上す るとみることができる。

このように，比較する対象によって HSY の得失の見方 
表 1 試作機の仕様

Table 1. Specifications of test machine.

\begin{tabular}{|c|c|c|c|c|}
\hline 定格虫力 & $20 \mathrm{~kW}$ & & 極 数 & 8 \\
\hline 定格 要压 & $200 \mathrm{~V}$ & & 周波数 & $200 \mathrm{~Hz}$ \\
\hline \multicolumn{2}{|c|}{ 電機子鉄心外径 } & \multicolumn{3}{|c|}{$195 \mathrm{~mm}$} \\
\hline \multicolumn{2}{|c|}{ 要機子铁心内径 } & \multicolumn{3}{|c|}{$135 \mathrm{~mm}$} \\
\hline \multicolumn{2}{|c|}{ 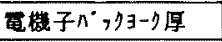 } & \multicolumn{3}{|c|}{$12.5 \mathrm{~mm}$} \\
\hline \multicolumn{2}{|c|}{ 電機子跌心全長 } & \multicolumn{3}{|c|}{$175 \mathrm{~mm}$} \\
\hline \multicolumn{2}{|c|}{ ギャップ長 } & \multicolumn{3}{|c|}{$0.65 \mathrm{am}$} \\
\hline \multicolumn{2}{|c|}{ スロット数 } & \multicolumn{3}{|c|}{36 (每極每相 $x$ 口 フ擞1.5） } \\
\hline \multicolumn{2}{|c|}{ 䨐機子巻線方式 } & \multicolumn{3}{|c|}{ 二層分布重格缺 } \\
\hline \multicolumn{2}{|c|}{ 界磁コイル巷回数 } & \multicolumn{3}{|c|}{ 176回 } \\
\hline \multicolumn{2}{|l|}{ 永久磁石 } & \multicolumn{3}{|c|}{$\mathrm{Nd}-\mathrm{Fe}-\mathrm{B}$ 磁石， $\mathrm{Br}=1.1$} \\
\hline
\end{tabular}

も異なるが，一般的には, PMSYとFWSYの両特性を 兼ね備えた中間的同期機であると位置づけることができ， 積極的に界磁制御を行うような用途に適していると考えら れる。

$\langle 2 \cdot 4\rangle$ 試作機の概要 試作機の概略の仕様を表 1 に 示す。前述の原理図では 6 極機を例としているが，構造上 任意の極数での製作が可能となる。ここでは，定格出力お よび電源周波数と 1 極分磁石の大きさとのかねあいから8 極機とした。なお，本試作機は機能確認のための試作機の 結果 ${ }^{(6)} よ り$, 磁石の種類, 界磁巻線巻回数などを見直し たものである。

\section{HSY の特性解析}

ここで, 表 1 に示す試作機を対象に有限要素法による磁 界解析を試みる。HSY の磁束の経路は三次元的であり䢃 密には三次元解析が必要となるが，ここでは近似的な解析 モデルを考え，実用的な二次元非線形解析を中心に検討を 進めることにする。

〈3・1〉解析モデルと解析上の仮定 この場合, HSY の回転子に磁石極と鉄心極とが交互に存在していること, 本試作機の電機子巻線が分数スロット巻となっていること などから，解析モデルとしては 2 極分を考える必要があ る。また, 界磁巻線による起磁力は, その大部分がギャッ プ部に加わるため, ギャップ部に等価的な起磁力を与える ことで近似できる。これらのことを考慮すると，二次元も デルでも十分解析が可能となる。文献 (6)では, 回転子の 任意の位置での 2 極分断面をとり, 界磁巻線起磁力を与え るための電流をギャッブ面の両端に流すことで, 無負荷特 性の解析が良好に行えることを示している。しかし, 周期 境界条件を与えることができないため, 負荷時の解析が行 えない問題があった。

そこで，図 $3(\mathrm{a})$ 邨よび(b)に示すように，N極側お よび $\mathrm{S}$ 極側の磁石極部分，抢よび鉄心極部分をそれそれれ 組み合わせた二つのモデルを用意し，各々の解析結果を合 成することによって，負荷状態に関係なく特性計算に必要 なギャップ磁束が得られる方法をとることにした。これ は, 基本的に N 極側磁石極からでた磁束はバックヨーク を通り $\mathrm{S}$ 極側磁石極に向かい, S 極側鉄心極からでた磁

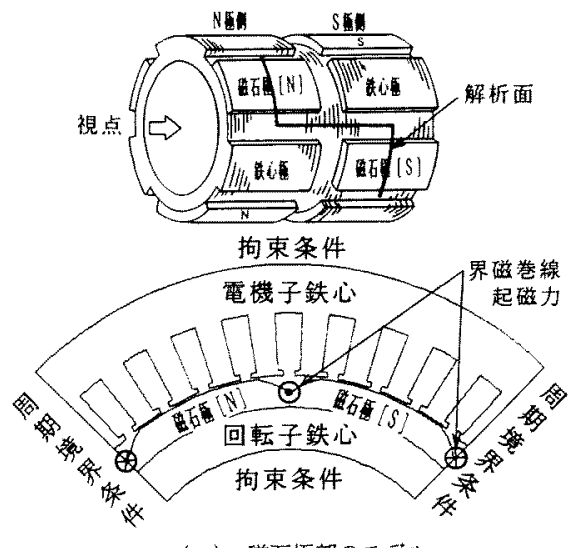

(a) 磁石極部のモデル

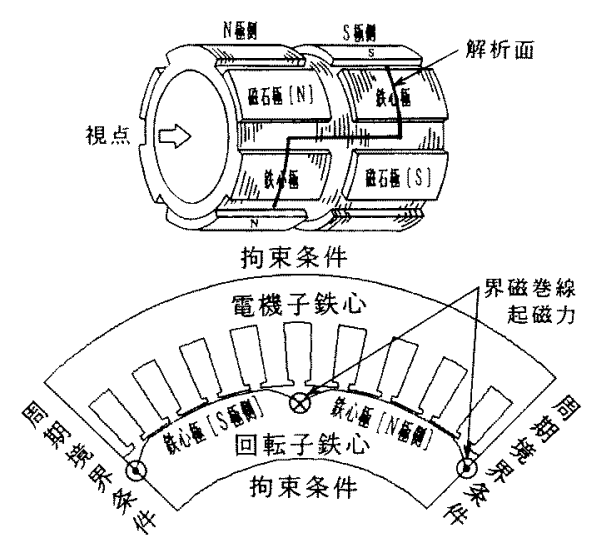

(b) 鉄心極部のモデル

区 3 解析モデル

Fig. 3. Analytical models.

束は同樣に $\mathrm{N}$ 極側鉄心極に向かうと考えることができる からである。実際に電機子抢よび回転子のバックヨークを 通る磁束については, 図 3 のモデルでは考慮できないが, バックヨークが厚く, 磁気的飽和の影響を受けないものと すれば，十分に実用的なモデルと考える。

図3に拈いて，円周方向の境界線にはポテンシャルを同 一とする周期境界条件を与え，鉄心内外径の境界線にはポ テンシャルを０とする拘束条件を与えている。また，界磁 巻線起磁力はそれぞれの極に扔ける磁界の大きさおよび方 向を考慮して，各極間のギャップ部に電流として与え，負 荷時には各スロットに電機子電流に相当する電流を両モデ ルに与えている。ただし，実際には一つの界磁巻線により $\mathrm{N}$ 極側と $\mathrm{S}$ 極側を励磁するので，このモデルでは実際の $1 / 2$ の界磁巻線起磁力となる。したがって, 試作機との混 乱をさけるために, 以下の検討に扔いて界磁電流扔よび起 磁力を諭ずる場合，すべて試作機に換算した值で示すこと にする。

〈3・2〉無負荷特性の解析 図3の解析モデルによる 無負荷時の解析結果の一例として, 図 4 に界磁電流 $10 \mathrm{~A}$ における磁束線図を示す。無負荷の場合, 永久磁石および 界磁巻線による起磁力が各極均等に加わるので, 磁束線図 
は磁石極部と鉄心極部の両モデルにおいてほほ同様となつ ていることがわかる。また，無急荷の状態では，界磁電流 を変化させることで磁束の量は変化するが，この磁束線図 の形自身梳とんど変化しないので, 他の界磁電流に対す る磁束線図は省略する。

実際の界磁巻線にそれぞれー5,0,5および $10 \mathrm{~A}$ を流し

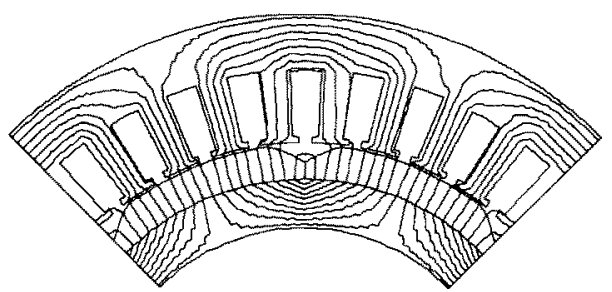

(a) 磁石極部

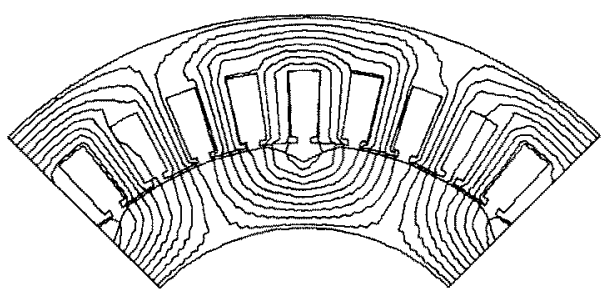

(b) 鉄心極部

図 4 無負荷時の磁束線図

Fig. 4. Flux plots at no-load condition.
たとして有限要素解析を行い，ギャップ部における磁束密 度分布を求めた結果を図 5 に示す。図 5 の左側の楯には磁 石極部のモデル，右側の欄には鉄心極部のモデルにおける 磁束密度分布を示している。各磁束密度待布は，モテルの 左端を原点として 1 周期分を表わしたものである。

また，実機では $\mathrm{N}$ 極側磁石極と $\mathrm{S}$ 極側鉄心極とが同一 軸上にあり， $\mathrm{N}$ 極側鉄心極と $\mathrm{S}$ 極側磁石極上が同一軸上 にあるので，電機子巻線に誘起される電圧は，図 5 の左欗 と右䦗に示主磁束密度分布の合成值（平均值）に比例する ことになる。この合成値の基本波成分を電機子巻線からみ た場合の等価ギャップ磁束密度と称することにする。この 等価ギャップ磁束密度の值も図 5 に併記してある。

図 5 より，界磁電流を変化させることによって，磁石極 部分の磁束はほほ一定に保たれているものの，鉄心極部分 の磁束が堌減することが確㒛でき，その結果として両者の 合成値である等価ギャッブ磁束密度の值が調整できること がわかる。

以上の解析界磁電流変化させて数点行い, 界磁電流 に対する等価ギャップ磁束密度を曲線にまとめると図 6 と なる。図6より明らかなように，等価ギャップ磁束密度は 界磁電流に対してほ浪直線的に変化する傾向にあるが，界 磁電流が大きくなると，特に電機子鉄心蒾部の磁気的飽和 の影響により，磁束密度の増加が頭打ちになることがわか る。

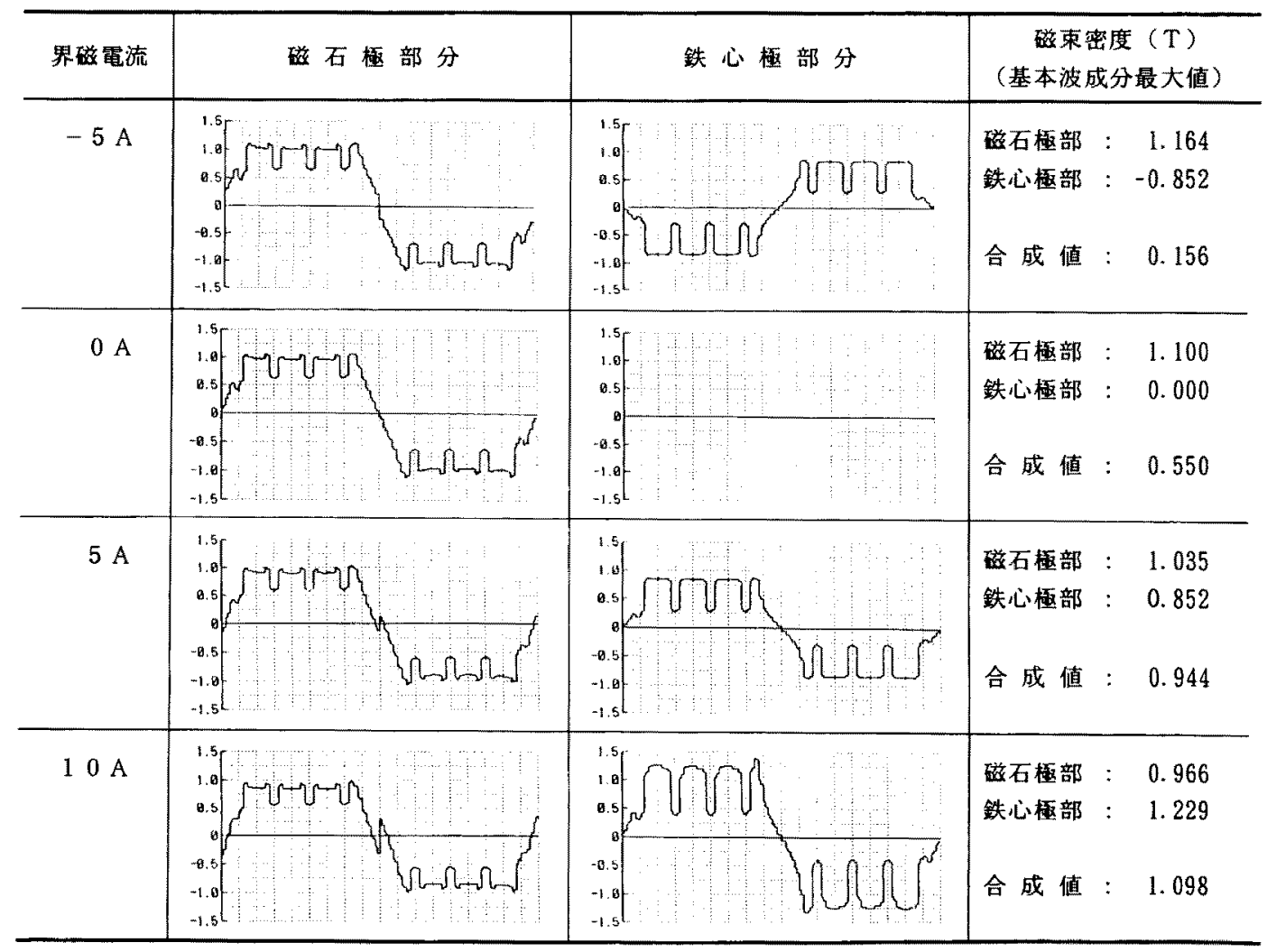

図 5 無負荷時の解析結果

Fig. 5. Simulation results at no-load condition. 


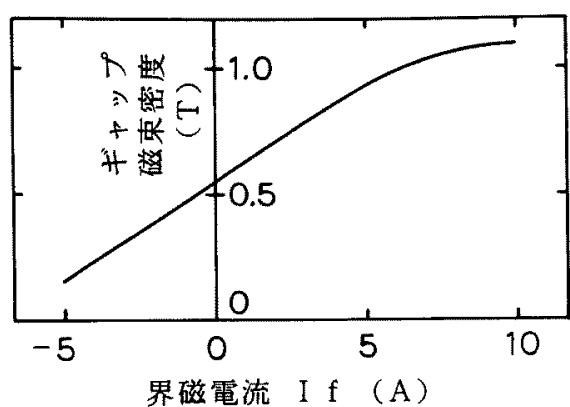

図 6 等価エアギャップ磁束密度

Fig. 6. Equivalent air gap flux density.

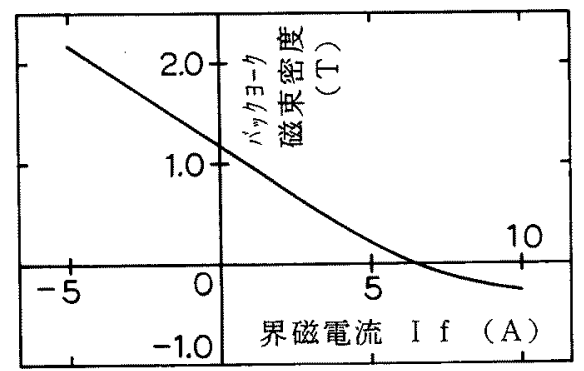

図 7 電機子バックコークの磁束密度

Fig. 7. Armature back-yoke flux density.

一方， $\mathrm{N}$ 極側あるいは $\mathrm{S}$ 極側のギャップ面における磁 束の総和がバックヨークを通して循環する直流磁束とな る。この值は, 図 5 の磁石極部と鉄心極部との磁束密度の 差と, ギャップ面積から容易に求めることができる。ま た, バックヨーク部の磁束密度は, この直流磁束とバック ヨークの断面積から得られる。これを, 回転子側に比較し て断面積が小さくなる電機子バックコークについて, 界磁 電流に対する曲線で表わすと図 7 となる。図 7 より,バッ クヨークを通る直流磁束は, 等価ギャッフ磁束を増加させ る場合に小となり，等価ギャップ磁束を減少させる場合に 大きくなることがわかる。界磁電流が 0 の場合でも，電機 子バックヨークの磁束密度は $1.2 \mathrm{~T}$ とっており, バック ヨークにおける磁気飽和の影響から，本試作機において は, 界磁電流 $I_{f} \geqq 0$ が実用的な等価ギャップ磁束の調整範 囲であることがわかる。したがって，等価ギャップ磁束を さらに減少させる必要がある場合には, 磁気飽和の影響を 考慮してバックヨーク厚を決定する必要がある。

な㧍，本計算結果は二次元非線形解析に基づいているの で,バックヨークにおける磁気飽和は考慮されていない。 したがって, 界磁電流が負となる範囲においては, 後述す るように実測值との誤差が大きくなる。

〈3・3〉 負荷特性解析法 HSY は電動機(7)としてあ るいは発電機(8) として応用できる可能性がある。しかし， ここでの目的は HSY の動作原理および基本特性を明確に することにあるので, 電機子巻線の誘起電圧と電機子電流 の位相関係が明確であると便利である。そこで, 誘起電圧 と電機子電流とが同期するような負荷運転を対象に解析を
進めることにする。具体的には, 磁石式 ACサーボモータ などで周知の制御方式 $\left(q\right.$ 軸電流のみを流す方式, 以下 $I_{d}$ $=0$ 制御と略記), 発電機としての力率 1 の負荷運転など がほぼこれに相当する。

HSYの定常状態に扔ける電圧方程式扔よびトルクの式 は，PMモー夕の式(2)に界磁巻線による磁束分を付加すれ ばよく，これを回転子の回転角速度に同期した回転 $d q$ 軸 上で表わせば(1)式および(2)式となる。

$$
\begin{aligned}
& V_{d}=R_{a} I_{d}-\omega L_{q} I_{q} \\
& \left.V_{q}=\omega L_{d} I_{d}+R_{a} I_{q}+\omega\left(\Lambda+M_{f} I_{f}\right)\right\} \\
& T=k_{t} \cdot\left\{\left(\Lambda+M_{f} I_{f}\right) I_{q}+\left(L_{d}-L_{q}\right) I_{d} I_{q}\right\}
\end{aligned}
$$

たたし， $V_{d}, V_{q}$ : 電機子相電圧の $d$ 軸, $q$ 軸成 分, $I_{d}, I_{q}$ : 電機子電流の $d$ 軸, $q$ 軸成分, $I_{f}$ : 直流界磁電流, $R_{a}$ : 電機子巻線抵抗, $L_{d}, L_{q}$ : 電機子巻線自己インダクタンスの $d$ 軸, $q$ 軸成 分， $\Lambda$ : 磁石による電機子巻線への鎖交磁束,

$M_{f}$ : 界磁巻線と電機子巻線との相互インダクタ

ンス， $\omega$ : 電源角周波数， $k_{t}$ : 定数である。

ここで，(1)式抢よび(2) 式をギャップ磁束に着目した 式で書き直せば( 3 )式抢よび(4)式となる。

$$
\left.\begin{array}{l}
V_{d}=R_{a} I_{d}-\omega\left(l_{a} I_{q}+K_{v} B_{q}\right) \\
V_{q}=R_{a} I_{q}+\omega\left(l_{a} I_{d}+K_{v} B_{d}\right)
\end{array}\right\}
$$

ただし（3)式および(4)式に扔いては以下の関係があ 吕。

$$
\left.\begin{array}{l}
K_{v} B_{q}=l_{q} I_{q} \\
K_{v} B_{d}=l_{d} I_{d}+\Lambda+M_{f} I_{f} \\
K_{t}=k_{t} \cdot K_{v}
\end{array}\right\}
$$

ここに, $l_{a}:$ 電機子巻線漏れインダタタンス, $l_{d}$, $l_{q}$ : 電機子反作用インダクタンスの $d$ 軸, $q$ 軸成 分, $B_{d}, B_{q}$ : ギャップ磁束のd 軸, $q$ 軸成分

(最大值)， $K_{u}, K_{t}$ : 定数である。

以上により，界磁電流および電機子電流に対するギャッ プ磁束密度の $d$ 軸抢よび $q$ 軸成分が求まれば, 端子電圧 挍よびトルクが計算できることになる。これらのギャップ 磁束密度は, 解析モデルに電流を与えて解析を行い, 等価 エアギャップ磁束を求め，これより磁束密度の $d$ 軸およ び $q$ 軸成分を求めればよいことになる。

一般に, 電機子電流が流れると電機子反作用磁束の影響 により磁気的な飽和が生じ，トルクの線形性が損なわれる が(10)，本方法では磁気飽和を考慮した磁束分布が直接得 られるので，より精度の高い解析が可能になると考える。

なお， $K_{v}$ 扔よび $K_{t}$ は電機子巻線の直列巻回数, ギャ ップの面積などによって決まり，本試作機の場合， $K_{u}=$

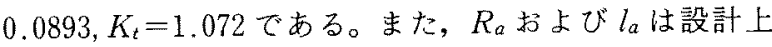
の定数を用い, $R_{a}=0.0449 \Omega, l_{a}=0.233 \mathrm{mH}$ としている。 また,ここでの検討は $I_{d}=0$ 制御を対象とするので，電機 子電流 $I_{a}$ は $I_{a}=I_{q}$ となる。

〈3・4〉負荷特性の解析結果図 8 に, 界磁電流を 10 


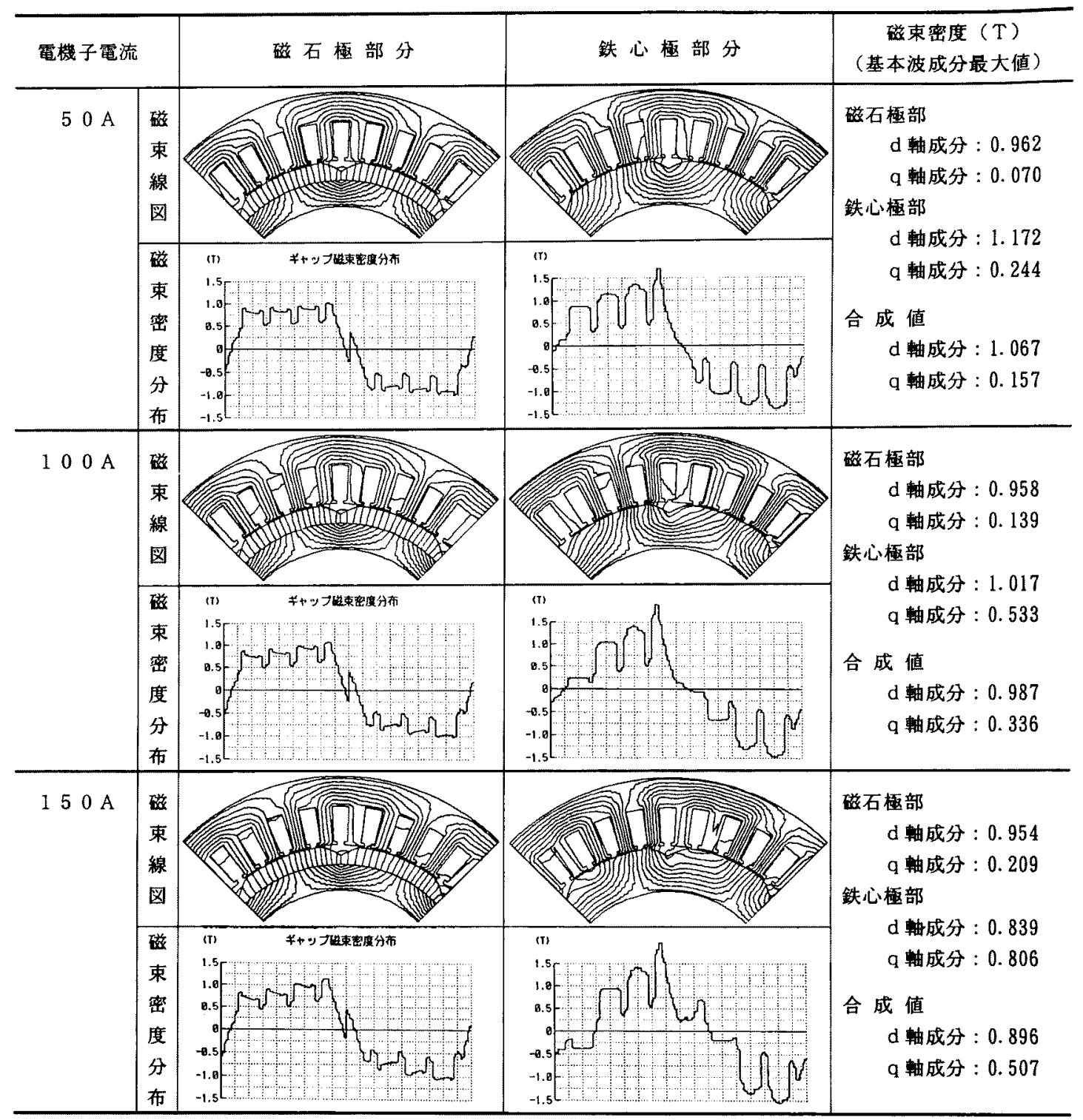

図 8 負荷時の解析結果

Fig. 8. Simulation results at loaded condition.

$\mathrm{A}$ 一定とし, 電機子電流を $50 \mathrm{~A}, 100 \mathrm{~A}$ および $150 \mathrm{~A}$ と した場合の解析結果を示す。困 5 と同様に, 左側の欄に磁 石極部のモデルによる解析結果，右側の欄に鉄心極部のも のを示しているが，同図では各状態における磁束線図およ びギャップ磁束密度分布の両方を示している。また, 磁石 極部と鉄心極部の磁束密度, および等価ギャップ磁束密度 の $d$ 軸成分战よび $q$ 軸成分についても併記している。

図 8 より, 電機子電流を変化させた場合, 磁石極部の磁 束はほぼ一定に保たれるが, 鉄心極部の磁束が電機子反作 用の影響を受けて, ギャップ磁束分布の中心が $q$ 軸方向 にずれていくことがわかる。その結果, 電機子鉄心の蔽部 において局部的に大きな磁束密度となる場所が存在し, こ の部分で磁気的飽和が生じることになる。このため, 主磁 束が減少しトルクも小さくなることが予想される。
以上の解析を電機子電流を変化させて数点行い, 電機子 電流に対する等価ギャップ磁束密度の $d$ 軸成分扔よび $q$ 軸成分を求めると図 $9(\mathrm{a})$ 扝よび (b) となる。図 9 より明 らかなように, 電機子電流の增加に伴い, $d$ 軸磁束は磁気 飽和の影響を受けて, 界磁電流が正の領域では減少し, 負 の領域では增加することがわかる。また，電機子電流と $q$ 軸磁束の関係は, 界磁電流の影響も受けるものの, 電機子 電流が少ない場合にはほほ比例関係にあり, 電機子電流が 大きくなると飽和する傾向にある。これらの值を(3)式お よび $(4)$ 式に代入することで電機子電圧拈よびトルクを計 算することができる。

\section{4. 試験結果と考察}

$\langle 4 ・ 1\rangle$ 実験装置の構成と制御方式実験装置は, 試 


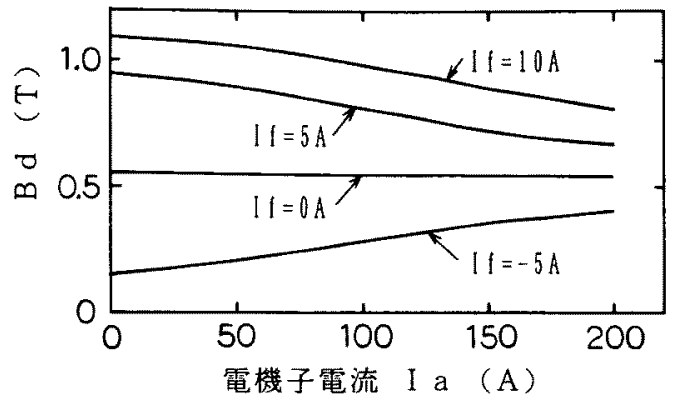

(a) $d$ 軸磁束密度

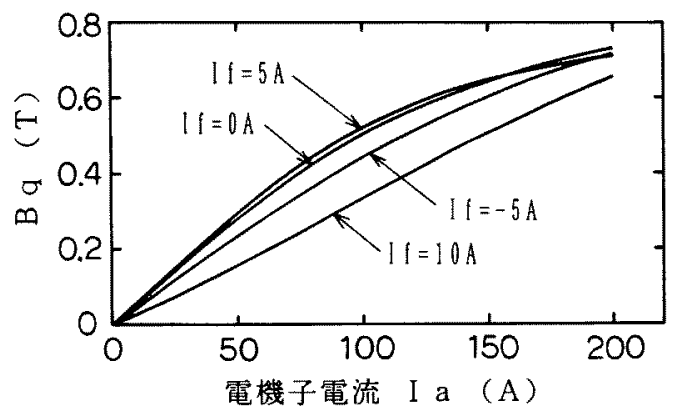

(b) $q$ 軸磁束密度

図 9 等価ギャップ磁束密度と電機子電流の関係 Fig. 9. Equivalent gap flux density vs. armature current.

作機を動力計に直結して，これを一定速度で制御すること によって，無負荷試験扔よび負荷試験が可能となるように 構成されている。HSY 駆動用のインバータはIGBTを用 い，搬送波周波数を $7 \mathrm{kHz}$ としている。また，界磁電流 調整用の励磁電源は 4 象限チョッパにて構成している。こ れらのインバー夕および励磁電源に適当なトルク指令，界 磁電流指令を与えることにより任意の負荷を与えることが できる。また，電圧拈よび電流はディジタルパワーメータ により、トルクは動力計により測定している。

なお，負荷試験に括けるHSYの制御ブロック図は図 10 のとおりであり，ここでは $I_{d}=0$ 制御を行っている。 インバータの電流制御系扝よび座標変換部はソフトウェア で処理しておう，界磁電流制御はアナログ回路で実現して いる。

〈4·2〉無負荷特性試験結果 図 11 に回転数を 3000 , 2000 および $1000 \mathrm{rpm}$ として, 界磁電流を変化させたとき の電機子巻線誘起電圧の実測值を示す。また，同図には図 $6 の$ 等価ギャップ磁束密度と電機子巻線の実効巻回数とか ら得られる誘起電圧の計算値も示している。

実測値における誘起電圧の推移は，図 11 の曲線に示す ように, 界磁電流の增加とともに各曲線の下側の曲線を通 り最大值に達し, 最大值より界磁電流の減少とともに各曲 線の上側の曲線を通り最小值に達している。界磁電流に対 する誘起電圧の変化がこのように線形的ではなく，かつヒ ステリシス特性となっているのは，磁気飽和および鉄心極 の残留磁束の影響であると考えられる。また，計算值は界

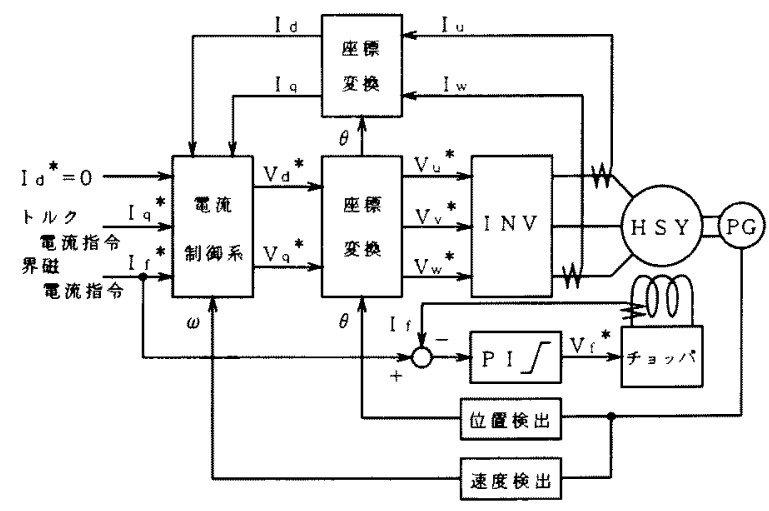

図 10 HSY 制御システム

Fig. 10. Control system of HSY.

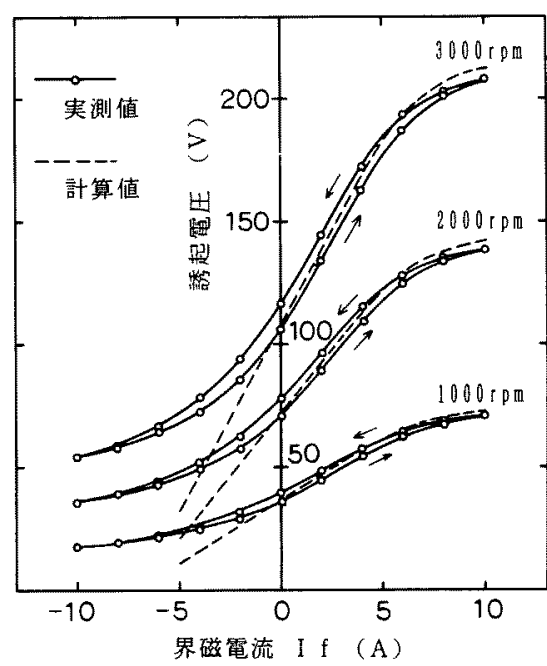

図 11 HSY の無負荷飽和曲線

Fig. 11. Saturation curves of HSY.

磁電流が正の領域では実測值と比較的よく一致するが, 直 流界磁電流が負となる領域では, 前述のバックヨーク部の 磁気飽和の影響により䛊差が大きくなることがわかる。

本試作機では，実用的な使用範囲を界磁䉓流が正の領域 として設計しているが，この結果をもとにバックヨーク厚 などを検討すれば，界磁電流が負となる領域にもHSYの 使用範囲を拡大できるものと考える。

〈4・2〉負荷特性の実験結果 負荷特性の一例として, HSY を電動機として駆動し, 回転数を $1000 \mathrm{rpm}$ 一定と した場合のトルクおよび端子電圧特性を図 12 および図 13 に示す。制御方式は $I_{d}=0$ 制御とし，界磁電流をパラメー タとして電機子電流に対するそれぞれの特性を示してい る。両図より,トルクおよび端子電圧は, 界磁電流が大き いほど増大し，界磁制御が効果的に行われていることがわ かる。

また，電機子電流に対するトルクの変化は，界磁電流が 0Aの場合にほぼ線形となっているが，界磁電流を大とす るほどトルクが飽和する傾向にある。これは，界磁電流が 大きいほど鉄心極部の磁束密度が高くなり，さらに電機子 


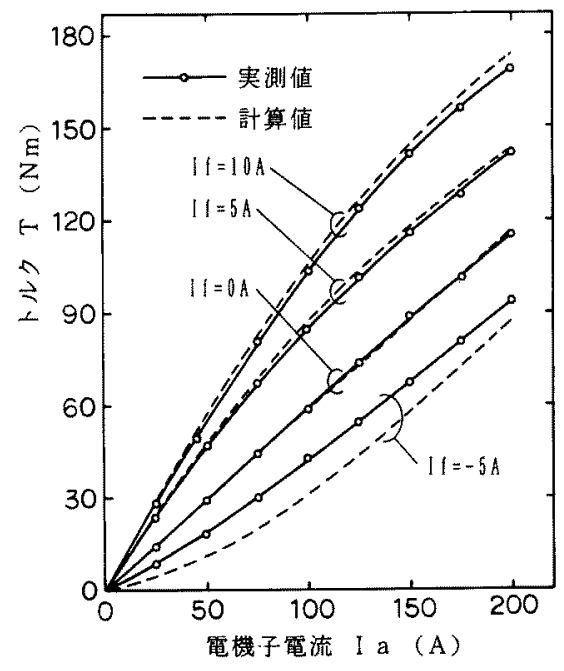

図 12 電機子電流一トルク電流

Fig. 12. Characteristics of torque vs. armature current.

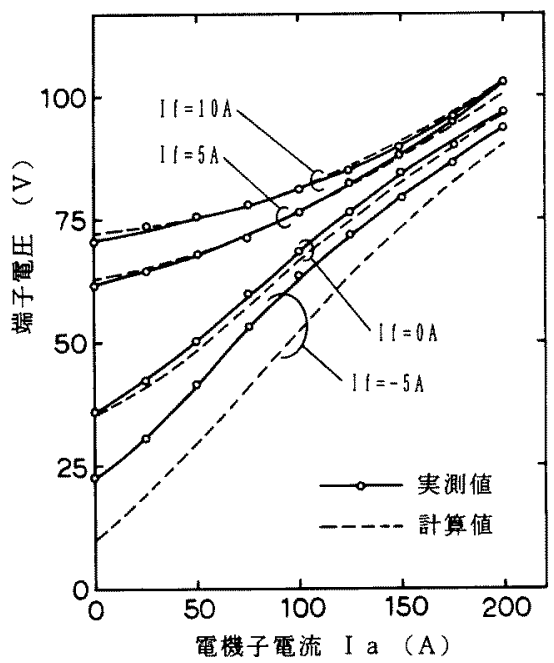

図 13 電機子電流-端子電圧特性

Fig. 13. Characteristics of voltage vs. armature current.

反作用による磁束が重鲳されるために，磁気的飽和の影響 が大となるためである(10)。

解析結果と比較すれば，実用的使用範囲である界磁電流 が正の領域では，トルク，端子電圧とも実測值と計算值が 良好な一致を示しており，本解析法で十分設計に対応でき るものと考える。なお，界磁電流がー5Aの場合におい ては, 電機子バックヨーク部の飽和の影響が大きいため実 機での減磁効果が小となり, 計算值よりも実測值のほうが トルク，端子電圧とも大きくなっている。

これらの結果から, HSYの動作原理扔よびその基本特 性が理論的，実験的に明確にできたものと考える。また， HSYでは界磁制御が良好に行い得るので, 高機能同期機 として種々の用途に応用が可能であると考える。
なお゙，HSYの電動機および発電機としての特性の明確 化，最適な制御方式の確立などの応用面についての詳細検 討は今後の課題とする。

\section{5.あとがき}

ここでは永久磁石界磁と直流界磁巻線とを備えたハイブ リッド励磁形同期機（HSY）を提案し，主としてその動 作原理および基本特性を理諭的扝よび実験的に明確にし た。

明らかになった要点は以下のようである。

（1）HSYの界磁起磁力は，永久磁石と直流界磁巻線 による起磁力との合成となる。このため, 永久磁石が一定 の起磁力を分担し，必要起磁力の過不足分を界磁巻線から 供給することになるので，小さな励磁容量で界磁制御を行 うことができる。

（2）無負荷特性ならびに負荷特性の実験結果より, 無 負荷誘起電圧特性, 負荷時のトルク特性および端子電圧特 性などが界磁電流の向きおよび大きさにより効果的に変化 し，界磁制御が良好に行い得ることが確認できた。

（3）理論解析においては，回転子の磁石極部分と鉄心 極部分とを分離した二次元磁界解析モデルを提案し, 解析 結果と実験結果とを比較検討した。この結果, 無負荷試験 および負荷試騟において良好な一致を示し, HSYの動作 原理および基本特性が理論的および実験的に明確にできた ものと考える。

（4）以上の結果より，HSYでは界磁制御を容易に行 うことができ，そのための励磁入力も小さくできるので, 高効率でかつ汎用性を持たせた高機能同期機として, 界磁 制御の必要な種々の用途への応用が可能であると考える。 (平成 7 年 1 月 30 日受付，同 7 年 6 月 5 日再受付)

\section{文献}

(1) B.K. Bose: "A high-performance inverter-fed drive system of an interior permanent-magnet synchronous motor drive", IEEE Trans. Industr. Applic. IA-24, 987 (1988)

（2）森本・畠中・董・武田・平紗：「PM モー夕の弱め磁束制御在用 いた広籍囲可変速運転」, 電学論 D, 112, 292 (平 4-3)

（3）水野・吉田・山田・小林：「㴽遵電動機と永久磁石式電動機の定 出力璉転領域に扔ける特性比較」, 電気学会産業電力電気応用研 資, IEA-93-20 (平 5-7)

（4）木本：「高速特殊発電機とその応用」，神鋼電機技報，114， 32, 112 (昭 62)

（5）永山・水野・堀・市原・小林：「フラシンス同期機に颃ける新后 磁方式の提案」, 平6電気学会全大, No. 863

（6）水野・永山・堀・古原・足利・小林：「ハイブリッド励磁形同期 機の一楧成法と基本原理」, 平 6 電気学会産業応用全大, No. 25

（7）永山・水野・足利・小林：「ハイブリッド励磁形同期電動機のト ルク特性」, 平 7 電受学会全大, No. 996

（8）永山・水野・足利・森・小林：「ハイブリッド励磁形ブラシレス 同期機の発電機特性」, 電気学会半導体暼力変換研資, SPC-94105 (平 6-12)

（9）千葉：「超高速 ACドライブ技術とその応用例」, 平6 電気学会 全大, No.S.9.8

（10）寺鵿・足利・氷野・山本・名取・藤原：「4 输媐動高性能電気自 動車用 $\mathrm{AC}$ ドライブシステム」, 電学婨 $\mathrm{D}, 114,33$ (平 6-1) 


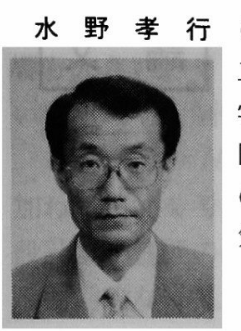

（正員） 1956 年 7 月 22 日生。 1981 年 3 月中部

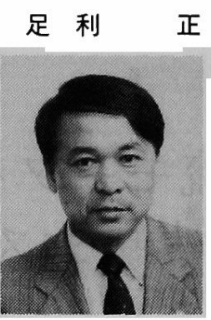

正（正員） 1954 年 12 月 21 日生。1975 年 3 月秋田 工業大学大学院工学研究科博士前期課程電気工 学専攻修了。同年 4 月(株)明電舎入社。現在, 同社電動カシステム工場にて, 主として回転機 の研究開発に従事。工学博士。1981，1990 年電 気学会論文賞受賞。

永山和 俊 (正員) 1968 年 12 月 8 日生。1993 年 3 月明治 大学大学院工学研究科博士前期課程電気工学専

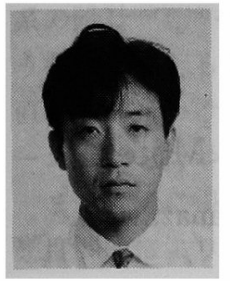
攻修了。同年 4 月 (株) 明電舎入社。現在, 同社 電動力システム工場にて, 主として電動機制御 の研究開発に従事。

小林忠夫（正員） 1943 年 5 月 8 日生。1967 年 3 月北海道

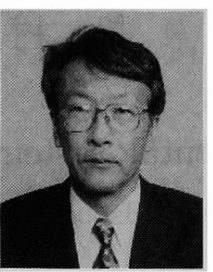
大学工学部電気工学科卒業。同年 4 月(株) 明電 舎入社。同社電力機器工場を経て, 現在, 電動 カシステム工場 $\mathrm{EV}$ 開発部長。この間, 主とし て半導体電力変換装置の研究開発に従事。 工業高等専門学校電気工学科卒業。同年 4 月 (株) 明電舎入社。現在, 同社電動力システム工 場にて, 主として電動機制御の研究開発に従事。 1992 年オーム技術賞受賞。 